\title{
Verdict Prison For Drug Abuse
}

\author{
Fahmi Reza ${ }^{1}$
}

Abstract. Drug abuse crime is becoming increasingly widespread, especially among the younger generation where the younger generation is the main pillar of a nation that can endanger the survival of the nation in the future. There is a difference of perception between law enforcement regarding the criminalization of the offenses related to drug abuse convictions were deemed less appropriate prison committed against to drugs. Scriptwriting non study was conducted using literature study using laws in Act No. 35 of 2009 challenged the Narcotics and the Supreme Court Circular No. 4 of 2010placement of abuse, abusers and drug addicts into rehabilitation institute of medical and social rehabilitation. The conclusion of this script writing is that the administration of prison sentences against offenders in this respect addicts who are victims of drug abuse should not be done and prioritize rehabilitation verdict.

Keywords: Verdict Prison; Drug Abuse; Rehabilitation.

\section{Introduction}

Drugs is an abbreviation of Narcotics and Drug dangerous which is a group of substances which, when entered into the body either by mouth, snorted, or injected into the blood affects the central nervous system / brain so that when misused (taken to excess) can cause physical impairments, psychological and social functions as well as having a risk of addiction for users. In the medical world drug is commonly used by physicians to anesthetize the patient will perform the operation. According to the Act No. 35 of 2009 on Narcotics are substances or drugs derived from plant or not plant, either synthetic or semisynthetic yan gdapat cause a decrease or change kesadara, loss of pain and may lead to dependence.

The spread of drugs now more suits to be prevented, given access to drugs is becoming ever easier of persons - persons who are not responsible. For example, the drug dealers can easily distribute these illicit goods in local schools, discos, brothels and places - the gang association. The number of drug users in Indonesia Tarus increased, rising drug users in Indonesia is proportional to the widespread circulation of the prohibited items. According to the Director of the Police Narcotics Detective Jaya Across Indonesia there are 1-5 million drug users where 600 thousand - 1.2 million users in Jakarta. This shows that this drug abuse crime becomes increasingly widespread, especially among the younger generation where the younger generation is the main pillar of a nation that can endanger the survival of the nation in the future. The young generation is the future is expected to become the nation's next each day increasingly fragile undermined by drugs. As a result, hopes for the emergence of the next generation of intelligent and resilient now a distant memory. Not only affects teenagers, victims of drug abuse now increasingly penetrated to adults and even children. As a result, hopes for the emergence of the next generation of intelligent and resilient now a distant memory. Not only affects teenagers, victims of drug

\footnotetext{
${ }^{1}$ Student of Masters (S2) of Law Faculty of Law Unissula Semarang and Members of the Police email Rezafhm268@gmail.com
} 
abuse now increasingly penetrated to adults and even children. As a result, hopes for the emergence of the next generation of intelligent and resilient now a distant memory. Not only affects teenagers, victims of drug abuse now increasingly penetrated to adults and even children.

Drug eradication efforts were already very often carried out by the government. Various attempts were made to solve crimes ranging from drug abuse pemebrian appeals via the mass media, banners and posters, socialization of No Drug, routine urine examination against government officers, the establishment of the National Narcotics Agency, the enactment of No. 35 of 2009 on Narcotics and others. However, the efforts made by the government will not reduce the rate of drug abuse without support and participation of the community itself.

Countermeasures against crime drug abuse by the government through the National Narcotic Agency (BNN) is carried out in three phases, namely prevention, enforcement and rehabilitation. Prevention is done through an appeal in the media, advertising on television, socialization to school and others. Repression against the elements that drug dealers conducted by the police and BNN. Rehabilitation conducted by the government through the BNN. Various efforts made by the government of course having some problems. Among them is the difference perepsi and understanding of the application of the Act - law by law enforcement officials in interpreting the meaning of Act No. 35 of 2009 on narcotics. Based on the author's experience as a Police Narcotics Investigation Adj Katingan Central Kalimantan Police in handling the criminal case against abusing drugs either as a drug or as consumers often judge gives a verdict of imprisonment against both parties. Not a problem terhdap traffickers because it is appropriate that they be imprisoned. Yet another case with users, some assume that the user is actually a victim of crime drug abuse. A right for a user to be free of drug addiction which is expected to be towards the user in this case to get the victims of drug abuse rehabilitation verdict.

Based on the foregoing illustrated that has occurred on disagreements over their prison sentences on victims of drug abuse. For that I am interested to discuss on how best verdict on drug abusers?

\section{Discussion}

As we know besama that abuse Narcotics is a crime. The criminal act is human behavior defined in the law, against the law, which should be convicted and done with errors. People who commit criminal acts will be held accountable by the criminal act when he has a fault, if the person has an error at the time of committing show the community in terms of normative view of the mistakes made. ${ }^{2}$ The offense is also said to be the act of doing or not doing something that has an element of error as prohibited and punishable by, where the criminal punishment of perpetrators is for the sake of maintaining law and order and ensuring the public interest. Thus it is clear that drug abuse is an act for the sake of maintaining security and order must be carried out strictly law enforcement that the convicted criminal. Drug abuse was conducted sellers (dealers, airports), courier, and users (users, addicts).

Law enforcement, as defined simply by Satjipto Rahardjo, is a process to realize the desires

\footnotetext{
${ }^{2}$ Andi Hamzah 2001 Bunga Rampai Hukum Pidana dan Acara Pidana Jakarta Ghalia Indonesia p. 22.
} 
of the law become a reality. ${ }^{3}$ The desires of the law is meant here is that the thoughts of legislature bodies defined in the legal regulations. Formulation mind legislator set forth in the rule of law, law enforcement also determine how it is run.

Furthermore, according to the Dirdjosisworo Soerjono conceptually law enforcement efforts made by combining various elements relating to the judicial mechanism that can be described as follows:

- Enhancement and utilization of law enforcement agencies, including the strengthening of the organization, personnel and infrastructure to solve criminal cases.

- Legislation can function analyze and stem crime and have reach into the future.

- Effective criminal justice mechanisms with the requirements of fast, accurate, inexpensive and simple.

- Coordination among law enforcement agencies and other government officials related to improve the effectiveness in the prevention of crime.

- Community participation to help facilitate the enforcement of criminality.

In connection with the foregoing the Government has issued regulating on Narcotics. In Act No. 35 of 2009 on Narcotics explained that drug addicts are people who use or misuse of narcotics and in a state of dependence on narcotics, up physically and psychologically. Also in the Act 35 of 2009 is explained also that drug dependence is a condition characterized by an urge to use drugs continuously - going with doses increased in order to produce the same effects and if their use is reduced and psychological symptoms are typical.

The next thing that is described in the Act No. 35 of 2009 which is about abusers of narcotics are people who use narcotics without authority or unlawfully, rehabilitation Medical by Act No. 35 of 2009 is a process of treatment in an integrated manner to free addicts from dependence narcotics.

In accordance with the explanation of the criminal offense above that drug abuse is a crime and in order that the creation of order in society then against this act should be giving criminal penalties ${ }^{4}$. However in applying criminal sanctions against those involved in acts of abuse of narcotics crime not done blindly. A drug addict in accordance with the above explanation can be categorized as victims in the event of this drug abuse. With the imprisonment verdict against the user in this case the actual drug addicts such measures do not resolve the problem. Interactions that occur every day between users and drug dealers in the Penitentiary did not rule out the user is even going to be more severe and can even become a dealer infected after being released from prison. In the Act No. 35 of 2009 also regulated the obligation to rehabilitate addicts narkotika.Berikut This is an article in Law No. 35 of 2009 which regulates the obligation for addicts to undergo rehabilitation:

- Article 54

Narcotics addicts and victims of abuse of narcotics required to undergo medical rehabilitation and social rehabilitation.

- Article 55

- The parent or guardian of Narcotics addict minors must report to the health center, hospital, and / or the medical rehabilitation and social rehabilitation appointed by

\footnotetext{
3 P.A.F. Lamintang 1996 Dasar-Dasar Hukum Pidana Indonesia. Bandung PT. Citra Adityta Bakti p.16

${ }^{4}$ Andri Winjaya Laksana 2015 Tinjauan Hukum Pemidanaan Terhadap Pelaku Penyalahguna Narkotika Dengan Sistem Rehabilitasi in Jurnal Pembaharuan Hukum
} 
the Government for the treatment and / or treatment through medical rehabilitation and social rehabilitation.

- Narcotics addicts who are old enough are obliged to report themselves or reported by his family to the community health center, hospital, and / or the medical rehabilitation and social rehabilitation appointed by the Government for the treatment and / or treatment through medical rehabilitation and social rehabilitation.

- Provisions concerning the mandatory reporting as referred to in paragraph (1) and (2) regulated by Government Regulation

- Article 103

1) Judges who hear cases Narcotic Addicts can:

- decide to order the treatment and / or treatment through rehabilitation if the Narcotic Addict guilty of the crime of Narcotics; or

- set to order the treatment and / or treatment through rehabilitation if the Narcotic Addicts are not guilty of the crime of Narcotics.

2) The period of treatment and / or care for Narcotics addict referred to in paragraph

(1) letter a calculated as serving time period.

- Article 127

(1) Every Abuse To:

- Narcotics Group I for myself is liable to imprisonment for a period of 4 (four) years;

- Narcotics Group II for yourself is liable to imprisonment for a period of 2 (two) years; and

- Narcotics Group III for themselves shall be punished with imprisonment for a period of 1 (one) year.

(2) In deciding the case referred to in paragraph (1), the judge shall take into account the provisions referred to in Article 54, Article 55 and Article 103.

(3) In terms of Abuse order referred to in paragraph (1) can be proved or proved to be the victim of abuse of narcotics, Guna Abuse shall undergo medical rehabilitation and social rehabilitation,

Law enforcement against criminal acts performed pursuant drug abuse Act No. 35 of 2009 on narcotics. In the Act explicitly outlined in article 54 that the drug addicts and drug abusers shall undergo medical rehabilitation and social rehabilitation. Handling the crime of drug abuse conducted by the police, BNN, prosecutors and judges. Investigations conducted by the police and BNN, the prosecution conducted by the prosecutor and the judge in charge of hearing. In judicial matters the judge has the authority also set forth in Act No. 35 of 2009 which in article 103, which reads:

Judges who hear cases Narcotic Addicts can:

1) Disconnecting to order the treatment and / or treatment through rehabilitation if the

Narcotic Addict guilty of the crime of Narcotics; or

2) set to order the treatment and / or treatment through rehabilitation if the Narcotic Addicts are not guilty of the crime of Narcotics.

However, in giving sentence against the crime of drug abuse judge also obliged to observe the provisions contained in article 127 of the Act No. 35 of 2009 which reads:

Every Abuse To: 
- Narcotics Group I for myself is liable to imprisonment for a period of 4 (four) years;

- Narcotics Group II for yourself is liable to imprisonment for a period of 2 (two) years; and

- Narcotics Group III for themselves shall be punished with imprisonment for a period of 1 (one) year.

This is what causes the differences of opinion among law enforcement agencies. On the one hand, the rise of drug abuse in society requires law enforcement agencies to act decisively to punish weighing all the parties involved in the trafficking and drug abuse, but on the other hand decisive action with that without careful consideration of the abusers of drugs does not solve the problem of overcoming the problems widespread circulation and drug abuse. This is because most people believe that drug abusers are victims or people who are sick and very unwise when people mix people who are sick with other criminals.

In the rehabilitation of addicts sentencing judge should consider - as follows:

- Drug addict is a person who uses drugs and dependence both physically and psychologically

- Victims of abuse is someone who pays no deliberate use of drugs because lured, tricked, deceived or threatened to use drugs

- Narcotics were seized from the time of arrest amounted addict one day and not for commercial use.

- Not shown to be involved in drug trafficking

- In order to do assasement against drug addicts in advance.

Besides arranged in Act No. 35 of 2009 on narcotics convictions against the crime of abuse of narcotics is also set in the Supreme Court Circular (SEMA) No. 4 of 2010 on the placement of abuse, abusers and drug addicts into rehabilitation institute of medical and social rehabilitation with the classification of criminal offenses as follows:

- Defendant at the time was arrested by police investigators and investigators BNN in a state caught red-handed.

- At the time caught in the act according to item $A$ above are found evidence of the use of 1 (one) day with the details as follows:

- Group methamphetamine (shabu) : 1 gram

- Group of MDMA (ecstasy) : $2.4 \mathrm{~g}=8$ pieces

- Heroin group

$: 1.8$ grams

- Cocaine group

- Marijuana Group

$: 1.8$ grams

- Koka Leaf

: 5 grams

- Mescaline

: 5 grams

- Group Psilosybin

: 5 grams

- LSD Group (d-lysergic acid diethylamide) : :2 grams

- PCP Group (Phencyclidine) : :3 grams

- Fentanyl group : 1 gram

- Methadone group : $0.5 \mathrm{~g}$

- Morphine group

: 1.8 grams

- Pethidine group

: 0.9 grams

- Codeine group

: 72 grams 
- Bufrenorfin group : $32 \mathrm{mg}$

- Letter Lab test positive for narcotics investigator Based on demand.

- Need Certificate of psychiatric / government psychiatrist appointed by the judge

- Follow-there is evidence that the person concerned involved in the illicit traffic of narcotics

With the SEMA No. 4 of 2010 further confirms that to the victims of drug abuse in order to be rehabilitated and to where does the rehabilitation process can be done in place that has been designated by the authorities.

\section{Closing}

\subsection{Conclusion}

Based on the above discussion the authors conclude that on the basis of criminal Act No. 35 of 2009 challenge Narcotics and supported by the Supreme Court Circular No. 4 of 2010 on the placement of abuse, victims of abuse and rehabilitation of drug addicts into social classification:

- Defendant at the time was arrested by police investigators and investigators BNN in a state caught red-handed.

- At the time caught in the act according to item $A$ above are found evidence of the use of 1 (one) day with the details of the tables of Law No. 35 of 2009

- Letter Lab test positive for narcotics investigator Based on demand.

- Need Certificate of psychiatric / government psychiatrist appointed by the judge

- Follow-there is evidence that the person concerned involved in the illicit traffic of narcotics

Thus, the provision of rehabilitation of abusers in this case a drug addict is a better action to perform than a prison sentence.

\subsection{Suggestion}

- To be a judge in a verdict for the criminal misuse of narcotics to put forward measures provide guidance than punishment alone.

- The rule of law - laws governing narcotics in order to avoid overlapping rules.

\section{Bibliography}

[1] Andi Hamzah 2001 Bunga Rampai Hukum Pidana dan Acara Pidana Jakarta Ghalia Indonesia.

[2] P.A.F. Lamintang 1996 Dasar-Dasar Hukum Pidana Indonesia. Bandung PT. Citra Adityta Bakti.

[3] Andri Winjaya Laksana 2015 Tinjauan Hukum Pemidanaan Terhadap Pelaku Penyalahguna Narkotika Dengan Sistem Rehabilitasi Jurnal Pembaharuan Hukum

[4] Act No. 35 of 2009 on Narcotics

[5] SEMA No. 04 of 2010 concerning the Placement Abuse abusers and drug addicts into rehabilitation institute of medical and social rehabilitation 